\title{
Lauter, Paul (2020), Our Sixties: An Activist's History
}

Maria Irene Ramalho

\section{(2) OpenEdition}

\section{Journals}

Electronic version

URL: https://journals.openedition.org/rccs/11755

DOI: $10.4000 /$ rccs. 11755

ISSN: 2182-7435

\section{Publisher}

Centro de Estudos Sociais da Universidade de Coimbra

\section{Printed version}

Date of publication: 1 May 2021

Number of pages: 203-205

ISSN: 0254-1106

\section{Electronic reference}

Maria Irene Ramalho, "Lauter, Paul (2020), Our Sixties: An Activist's History", Revista Crítica de Ciências Sociais [Online], 124 | 2021, Online since 26 May 2021, connection on 28 May 2021. URL: http:// journals.openedition.org/rccs/11755 ; DOl: https://doi.org/10.4000/rccs.11755 


\section{RECENSÕES}

\section{Teles, Filipe (2021), Descentralização e poder local em Portugal. Lisboa: Fundação Francisco Manuel dos Santos, 106 pp.}

O tratamento das temáticas político-institucionais deverá, na medida do possível, passar por algum foco comparativo, sob pena de a riqueza contextual dos trabalhos enfermar do reducionismo paroquialista ou do afunilamento explicativo. As influências estruturais que tocam hoje na vida organizacional de cada nação, comunidade ou território merecerão, pois, ser esboçadas, em nada isto obstaculizando ao conhecimento profundo do terreno empírico em causa.

Seguidamente, sabe-se como os objetos e noções dos estudos socioinstitucionais têm uma maior ou menor carga simbólico-ideológica. Trata-se do seu substrato normativo, ou político, suscetível de reações automáticas, pela associação a projetos de sociedade valorativamente distintos. Falar de democracia, participação, coesão social e identidades presta-se a esses automatismos, por regra alheios aos modos de existência real das matérias tratadas, na sua variabilidade concreta. Em sentido inverso, o evitamento destes obstáculos passa muitas vezes por trabalhos de pendor descritivo, de um comparativismo suave e generalizante, cuja repugnância pelo contributo filosófico, ético ou político exprimirá tão só uma consciência analítica indiferente ao curso das matérias, ou problemas, a cujo destino deveriam ajudar. A obra de Filipe Teles, Descentralização e poder local em Portugal, editada pela Fundação Francisco Manuel dos Santos, aborda uma das noções que mais boas vontades - doutrinárias e científicas - tem concitado, em particular na Europa e no continente americano. Essa noção é a da descentralização. O autor, com sólida especialização na área - pró-reitor da Universidade de Aveiro para o desenvolvimento regional e a política de cidades, faz parte do Governing Board da European Urban Research Association e do Steering Comittee do European Consortium for Political Research Standing Group on Local Government and Politics, coordena a secção de Governação e Política Local da Associação Portuguesa de Ciência Política e tem publicado trabalhos a nível nacional e internacional sobre governação local, metropolitana e regional, nos cenários europeu e português -, evita, porém, os escolhos acima sinalizados. Não renegando a confiança nas virtudes democráticas e técnicas da descentralização, trata-a em modo comparativo, na sua vertente eminentemente portuguesa e sem iludir as aporias (défices, patologias) que ela também evidencia. Falamos aqui da rede, por vezes indescortinável e labiríntica, de níveis, jurisdições, instituições e organismos a que a descentralização pode conduzir, com a correlativa falta de transparência e o difícil mapeamento de atribuições e responsabilidades; das inadequações de escala, que retiram eficácia e produtividade aos vários serviços e perímetros de intervenção; da falta de articulação ou cooperação multiníveis; da redundância de dispositivos e equipamentos; das lógicas de patrocinato, amiguismo e corrupção. Finalmente, na parte final do seu livro, Teles propõe um assumido aconselhamento sobre a evolução desejável 
das práticas de descentralização, a partir dos desafios em curso em diversos tipos de territórios, que podiam servir de compêndio ilustrativo aos decisores institucionais, mormente em Portugal.

Estamos, desta maneira, perante um estudioso que não negará a interdependência crescente dos sistemas políticos, em particular na Europa comunitária. Esta implica mútua aprendizagem, ritmada por enquadramentos legais e normativos comuns, que tornam os países europeus suscetíveis de inteligibilidade à luz de categorias e conceitos partilhados. Isso sem menosprezar a diferenciação de cada um destes países em termos de tradições constitucionais e histórias políticas, quadros institucionais e aparelhos administrativos, dimensões territoriais e níveis de desenvolvimento, responsáveis, no que à descentralização respeita, por diferentes assunções e concretizações das suas virtudes e defeitos. No seu trabalho, Teles procede a uma pedagogia terminológica e concetual, distinguindo significados e tipos de descentralização (política e administrativa), demarcando-os de procedimentos como a desconcentração e diferenciando-os das modalidades, mais ou menos centralizantes, de territorialização das políticas públicas. Para o caso português, não deixa de lembrar o paradoxo de ter municípios responsáveis por quase metade do investimento público direto, a par de uma reduzida capacidade em termos de despesa pública. Este é um sintoma da persistente e complexa centralização, bem entendido, do "problema sério de capacidade institucional, organizacional e de governação" ao nível dos municípios, que apenas vão buscar a sua dinâmica à implementação dos fundos comunitários, sem os quais seriam "insignificantes" (pp. 18-19). Isto remete para a velha discrepância entre os quadros formais (constitucionais e legais) do poder municipal em Portugal e as reais condições de exercício desse poder. E coloca os municípios portugueses a um nível muito mais baixo de capacidade institucional (autonomia decisória e financeira, liberdade de organização e captação de receitas, proteção face às interferências governamentais) nas comparações com homólogos europeus, enquanto permanecem reféns de lógicas pessoalistas, presidencialistas e clientelares de atuação. Globalmente sobressai neles a inércia organizacional, os problemas de representação e responsabilização de decisores, o fraco envolvimento de cidadãos, o isolacionismo paroquial, nesse panorama frágil e contraditório que é o da sua democraticidade e, genericamente, da inserção europeia dos territórios periféricos portugueses. ${ }^{1}$

Neste âmbito, embora a política de coesão europeia imponha um modelo de governação multiníveis, que desafia as tradições centralistas e obriga a modernizar serviços e competências, tanto dos poderes locais como das entidades regionais do Estado (Comissões de Coordenação e Desenvolvimento Regional), nada anula o efeito pernicioso da instabilidade e volatilidade das políticas locais - "um subproduto de incentivos nacionais", de estratégias gerais e condicionantes normativas (p. 78) -, da falta de clareza e energia da cooperação intermunicipal (marginal

\footnotetext{
${ }^{1}$ Cf. Ruivo, Fernando; Francisco, Daniel (2005), "Entre centre et périphéries: pour une esquisse des pouvoirs locaux au Portugal", Pôle Sud, 22, 115-125; Francisco, Daniel (2007), "When Adaptation Eludes Transformation: The Losing Game of the Portuguese Territories within the Context of Europe", Lusotopie, XIV(2), 11-33; Francisco, Daniel (2009), "Territories Named Desire: From the Breadth of Concepts to the Containment of Experience", RCCS Annual Review, 1, 3-35. Tradução de Monica Varese. DOI: 10.4000/rccsar.138
} 
nos esforços organizacionais e financeiros dos municípios), do facto de as estruturas intermunicipais adotarem "investimentos elegíveis para os fundos estruturais como prioridade, em detrimento das necessidades específicas identificadas nos territórios. Investe-se e projeta-se para onde há orçamento" (p. 83).

Em contraste, o autor assinala que na Europa a tendência é para a descentralização e regionalização efetivas das políticas públicas, a cooperação intermunicipal e a criação e capacitação de entidades metropolitanas. Paralelamente às reformas que buscam melhores soluções de escala, reduzindo-se o número de municípios ou procedendo à sua fusão (em sentido inverso, em Portugal só as freguesias foram alvo de reestruturação e redução), ficamos a saber que as melhores soluções passam pelo investimento na articulação multiníveis, na versatilidade e adaptabilidade das dimensões e responsabilidades $\mathrm{da}$ governação descentralizada, com sistemas de descentralização assimétrica (não são um "bicho-papão", diz Teles), onde as competências entre entidades homólogas variam consoante a natureza dos territórios e os problemas neles dominantes.

A esta luz, o autor propõe que a incerteza política, o desequilíbrio nas estruturas de decisão, a falta de clarificação de competências, a pouca confiança nas instituições, a volatilidade na articulação entre agentes, a deficiente capacitação institucional e técnica, e os obstáculos reiterados à capacidade de governação das entidades subnacionais em Portugal possam ser reduzidos com a montagem de sistemas integrados de decisão e intervenção da administração pública. Assim, poder-se-ia ultrapassar a complexificação e politização excessivas das formas de atuar no território, que apenas têm reforçado as derivas de uma "incomparável centralização". A desconfiança entre centro e periferia, a difícil relação entre instâncias e circuitos decisórios - locais e regionais, dos municípios e das entidades regionais do Estado, das comunidades intermunicipais e das áreas metropolitanas, enfim, das entidades políticas e administrativas - apenas bloqueia o advento de uma descentralização capaz de produzir políticas públicas que reflitam, realmente, as caraterísticas e preferências de cada território.

O livro de Teles oferece-se como uma breve síntese do estado da arte dos estudos e práticas da descentralização, na Europa e em Portugal. Num trabalho abreviado como se propõe, não poderia haver lugar ao aprofundamento temático. No entanto, o essencial das problemáticas tratadas nas obras de referência sobre o tema, em Portugal e sobretudo na Europa, está nele refletido. Com a vantagem de o olhar sobre a realidade portuguesa ser simultaneamente lúcido e empenhado, informado e crítico, pedagógico e construtivo.

Daniel Francisco

Revisto por Alina Timóteo

\section{Lauter, Paul (2020), Our Sixties: An Activist's History. Rochester: University of Rochester Press, 287 pp.}

Released in October 2020, Our Sixties: An Activist's History is Paul Lauter's new book, a fine piece of social history masterfully woven into a very moving, honest, and personal memoir. In carefully conceived
13 chapters tracing the various phases of the activist's history, the book combines history, politics, pedagogy, and theory. Beautifully written, it offers solid information and sound, sharp commentary on the 
events that marked the revolutionary era of the 1960s in the United States (US). The author's deep knowledge of American culture together with a bright sense of humor and a shrewd, witty tone, makes it a pleasure to read. Indeed, Our Sixties should be required reading for those who want to understand the civil rights movements in the US in the 1960s and the connected struggles against inequality, discrimination, segregation, oppression, racism, poverty, sexism - and war. As the author points out in the first chapter, though the word was never mentioned at the time (and is still largely scary today in the US), these were clearly socialist movements.

With a Yale $\mathrm{PhD}$ in his luggage (1958) and before he went on to pursue a brilliant career in academia, Lauter was a passionate activist for social justice. He traveled all over the country, helping develop peace education programs, teaching in the 1964 Mississippi freedom schools, heading the first community school (in Washington, D.C.), supporting draft opposition, resisting the war in Vietnam, and co-founding the Feminist Press. Our Sixties suggests that following the "success" in 2016 of Trump's self-serving "revolution" - act-now-for-America-first - the US urgently needs a 60's style progressive reinvention. The stunning cover of Our Sixties reproduces the well-known Warren K. Leffler's photograph of the civil rights march on Washington, D.C., on August 28, 1963. The event, also known as March on Washington for Jobs and Freedom, brought together 250,000 Americans. At the march, Martin Luther King, Jr., the final speaker, delivered his historic "I Have a Dream" speech in front of the Lincoln Memorial.
It was the perfect finale for an event intended to denounce racism, segregation and discrimination and to champion for the civic and economic rights of African Americans.

I see this cover image as the perfect reflection of Lauter's lifelong devotion to inclusive, democratic ideals and principles. He has recently stated that he "first encountered Black Lives Matter in 1964 in Mississippi". How could that be if Black Lives Matter didn't start until 2013? "As an organization", Lauter corrects, and he continues, "the issues addressed in the BLM movement have energized and unsettled black communities for decades". ${ }^{2}$ In the 1960s, when it was dangerous to try to help African Americans to get registered to vote - you could actually get killed, and many did - Paul Lauter was there. He went as a teacher only to find himself learning from his underprivileged Black and Latino and Latina students about American injustice.

By 1969, as the author tells us in chapter nine, after more than a decade of activism and political interventionist writing (listed at the end of Selected Bibliography, on pages 266-267), he decided to go back to academia. "I was weary", he confesses. And he needed a regular income to support his children (p. 154). But perhaps the more conservative turn after Nixon's election the previous year helped as well. The title of chapter nine couldn't be more fitting: “A New University?”. The question mark testifies to Lauter's modesty. From the 1980s on, particularly after he joined Trinity College, Hartford, in 1988, he led an effort to revolutionize higher education in the humanities and social sciences.

\footnotetext{
${ }^{2}$ See Lauter, Paul (n.d.), "Black Lives Mattered in 1964 in Mississippi, too. I Was There", Northjersey.com. Accessed on 11.11.2020, at https://eu.northjersey.com/story/opinion/2020/10/15/ black-lives-mattered-1964-mississippi-too-opinion/3643572001/.
} 
With a team of colleagues from around the country and overseas, he worked to expand the canon making English and American Studies theory, research, and pedagogy change completely. Even if not without controversy, English and American literature and culture syllabi in university departments could not but change as well.

In the meantime, as Our Sixties makes clear, Lauter was writing, co-writing, editing, and co-editing some of the most important and influential books in the field. The one having most impact still today is arguably The Heath Anthology of American Literature (1994), showing not only that Black writers matter, but that working class writers, indigenous writers, female writers, and all other writers also matter. After the Heath Anthology, students and teachers of American literature no longer had an excuse not to read and study and teach even Hawthorne's "damn'd mob of scribbling women". The neat, exclusive syllabus of American renaissance and other prominent white male authors, with the occasional token Emily Dickinson, Ralph Ellison or Tony Morrison, could no longer be the only one. Decolonized American studies had come of age. Major contributions to the same effect were Lauter's writings during the 1990s. Canons and Contexts came out in 1991, From Walden Pond to Jurassic Park, in 2001. In 1994-1995, Paul Lauter served as president of the American Studies Association. In that capacity he traveled the world (including a visit to the University of Coimbra, in Portugal, in
1995), delivering lectures and conducting seminars on the new American studies, and regularly participating in European Association for American Studies conferences, while back home the so-called "new Americanists" were furthering the same cause and exciting major controversy in the field. ${ }^{3}$

In March 2020 Lauter was scheduled to come back to Portugal to be the Americanist keynote speaker at the conference of the Portuguese Association of Anglo-American Studies, to take place in Aveiro. He had also graciously agreed to visit several Portuguese universities and research centers, including the Centre for Social Studies of the University of Coimbra, to speak about central issues of Our Sixties, then forthcoming. The COVID-19 pandemic completely ruined this project.

A distinguished, prize-winning scholar of English and American Studies, Paul Lauter is currently Allan K. and Gwendolyn Miles Smith Professor of Literature, Emeritus, at Trinity College, Hartford, Connecticut. A fine scholar, a committed teacher, and a concerned educator, Lauter never stopped being an activist. Once at Trinity, he set up an archive on the struggles of the American sixties and "began to work on this book, Our Sixties" (p. 217). The book makes things easier for whoever wants to know more about American culture and the ruthless affairs of the world in general, in order better to question them.

Maria Irene Ramalho Edited by Alina Timóteo

\footnotetext{
3 See Pease, Donald E. (1990), "New Americanists: Revisionist Interventions in the Canon", Boundary 2, 17(1), 1-37; and cf. the scathing critique of Crews, Frederick (1988), "Whose American Renaissance?”, New York Review of Books, 35(16), 68-69.
} 


\section{Rose, Michael (2020), Indigenous Spirits and Global Aspirations in a Southeast Asian Borderland. Timor-Leste's Oecussi Enclave. Amsterdam: Amsterdam University Press, 232 pp. *}

This book is a compilation of different stories that explore a common theme: the complex relation between the meto (the indigenous/familiar) and the kase (foreign) modes of life in the enclave of Oecussi, Timor-Leste. Written by anthropologist Michael Rose, the book draws on the author's experience in the region initially as a United Nations (UN) advisor and later on as a researcher.

The meto/kase relationship is discussed in the context of different dynamics at play in the highlands and lowlands of Oecussi and how they interact with each other. In Rose's words, "the practice of life in Oecussi is something that emerges from the contingencies of this "crossing", from movement between a highland space where meto matters and revolves around ritual/family/ /duty/agriculture that are imperative, and a lowland domain where money and outwardly orientated aspirations have become dominant in day-to-day life" (p. 36). In practice, kase and meto constantly connect and what often appears to be the dominance of the kase world actually reflects a more complex process, where kase is "enabled by the support of ever-present but typically invisible meto" (ibidem). It is this crossing and mobility process, and how it affects identity, that is at the heart of this study.

Theoretically, the analysis is influenced by three complementary approaches discussed in chapter one: theories of encounter, theories of change, and theories of experience. The work of James Scott is taken as a starting point to understand different forms of resistance to exogenous forms of governance and is complemented by theories of change and experience as Rose is interested not only in these interactions per se, but in how they evolve over time. The six chapters that follow dive deep into the experiences of local actors that navigate through the meto/kase realms while considering these three elements. Chapters two and three recount stories from 2011 and 2012, when the author was first in Oecussi as a young UN adviser to the Timorese government in a program devised to create employment and improve labour conditions in the district. As he recalls, the problems encountered were too complex to be reported in standard bureaucratic forms. They represented deep ontological tensions that local actors had to deal with, and which had bodily consequences that often resulted in misfortune, sickness and even death. This tension is exemplified in two different stories. In chapter two, Rose shares the story of a young man from Oecussi who went to study geology in Dili and, facing the tension between traditional beliefs and the new body of scientific knowledge, he actually suffered physical distress and sickness. Chapter three then presents the case of a man who once was a prominent entrepreneur and public servant in Dili and eventually, accused of embezzlement, became a pariah when he went back to his community. In both cases, while moving to urban contexts where kase modes of life prevails, these actors carried meto understandings which profoundly affected their life experiences.

\footnotetext{
Available at http://devpolicy.org/publications/books/MRose_indigenous-spirits-and-globalaspirations-in-a-southeast-asian-borderlandDevPol.pdf. Accessed on 09.04.2021.
} 
Chapters four to seven explore stories from 2014, when Rose went back to Oecussi as a researcher. Chapter four problematises the implementation of the Special Economic Zone (Zona Especial de Economia Social de Mercado em Timor-Leste, in the original), highlighting the role of spirits as agents of resistance to "high modernism". Chapter five recounts the work of a local Catholic healer, his collection of sacred stones and the incorporation of kase instruments to explain and validate the efficacy of his work. Chapter six tells the case of a public servant working in the government office charged with protecting the environment, who was also the nephew of a prince in Oecussi - the latter in charge of protecting the forest -, and how the kase and meto logics of these positions often conflicted. As these functions were based on different sites of legitimacy and different logics, this partly enabled his work by reinforcing his authority in Oecussi, but it also made it complicated as these different positions led to different attitudes related to rule enforcement.

Chapter seven juxtaposes two parallel events taking place in the village of Kutete: the reluctance of local farmers to adopt new agricultural methods, and a ritual speech performed in a local school to help students pass the exams and succeed professionally thereafter. While the first case reflects a clear resistance to kase methods, in the second case meto rituals were used to foster prosperity perceived according to kase ideas of success.

The rich description of these experiences, accompanied by constant reflexivity by the author, makes this book very engaging and easy to read. Throughout so many different stories, the meto/kase fluid relationship becomes very visible in all its complexity, confirming the argument that the distinction between these modes of life is not clear cut and that it must be understood from the point of view of experience. In Rose's words, "The good things of the outside world are pursued not through rejecting the meto ways of the village, or collapsing them into the kase, but through the ritually mediated and repeated negotiation of travel between them" (p. 227). While much of the discussion is framed within anthropological approaches, this book, which I vividly recommend, is of interest to academics and practitioners from different fields, particularly Development Studies and International Relations, as the relation between meto and kase is exemplar of the limitations of big international projects, not least in the context of international statebuilding, where the ultimate end is to create a new social contract "from scratch" (often ignoring already existing social contracts). The emphasis on experience is of particular importance. Often policy literature presumes a linear logic on how societies function and develop. Conversely, much of the critical academic literature on peacebuilding, also influenced by the work of Scott, often stresses the aspects of local resistance as the primordial element of these global/ /local encounters. In this book, Michael Rose shows how these dynamics are much more fluid and less distinct as it appears at first sight. Resistance to and the embrace of the kase world go hand in hand, and how they interact is in constant motion.

The emphasis on experience and narratives further contributes to a broader discussion on the constitution of knowledge. Drawing on postcolonial critique, Rose engages with a crucial question in the conclusion that is "what is deemed valid knowledge?". By trying to unveil local narratives, Rose found that the ways to legitimise knowledge have been changing in the meto realm, as "today fluency in and identification with ways of sense-making that are comprehensible and valued by the outside world have become 
prestigious and potentially lucrative" (p. 161). How this is affecting Oecussi - and indeed how these processes affect societies more generally - is an important matter worth investigating more thoroughly in future research. Academically, this discussion points to the fundamental need to question and dissect the role of critical academic thinking in interpreting societies. While this has been generally discussed by authors such as Boaventura de Sousa Santos and Linda Smith, this book offers solid empirical evidence of how crucial this task is and how "truths" can differ when comparing those of the person who experiences them and those of whoever analyses these experiences from the outside.

\section{Roberta Holanda Maschietto}

Edited by Alina Timóteo

\section{Micó, Josep Lluís; Coll, Patricia (2020), Hiperaceleración. La revolución digital en la época del coronavirus. Barcelona: Editorial Diëresis, 236 pp.}

Las nuevas tecnologías son consustanciales a nuestra realidad cotidiana. Progresivamente, como el día a día atestigua, un mayor número de trámites deben hacerse electrónicamente. Esta aseveración se ha acelerado, hasta límites inverosímiles hasta hace muy poco, como consecuencia de la pandemia del COVID-19. Nuestros hábitos, en prácticamente todos los sectores, se han visto modificados de manera abrupta. Los últimos acontecimientos suscitados han generado una aceleración de los distintos procesos de automatización de las máquinas, la robótica y la inteligencia artificial. Estas últimas -la Inteligencia Artificial y la robótica- han pasado, en tiempo récord, de amenaza a solución en un mundo poscoronavirus.

Muchas compañías han debido implementar las tecnologías de información y comunicación para poder seguir operando. La tecnología y los avances que son inherentes a la misma no deben ser reputados como un fin en sí mismo, sino que deben ser considerados un instrumento facilitador para el cambio, que resulta necesario cuando nos referimos a la digitalización. Las empresas, sobre todo aquellas de índole internacional -y que tienen cierta relevancia-, llevan tiempo preparando la implantación y consolidación de las nuevas tecnologías en sus procesos. Sin embargo, debido al confinamiento que, a nivel mundial, ha generado la crisis del coronavirus, se tuvo que priorizar el teletrabajo, y dar un salto sin precedentes para planificar el futuro a largo plazo. Aunque, en los comienzos, se activó un modo de emergencia, con la finalidad de garantizar el servicio que se venía prestando, meses después tales cambios tecnológicos siguen presentes e incluso van a más. En cualquier caso, todo ello ha puesto de manifiesto que la digitalización es una apuesta sin vuelta atrás que aporta múltiples prerrogativas como, entre otras, flexibilidad, celeridad y eficiencia. Si bien es bastante probable que, a nivel internacional, un importante número de empresas -incluyendo las pequeñas y medianas empresas- deban ajustar sus presupuestos, la inmensa mayoría es, con carácter simultaneo, muy posible que salvaguarden sus inversiones en tecnología digital. La pandemia ha dado lugar a una clara disrupción global de los negocios, poniendo de manifiesto la relevancia de las iniciativas en el ámbito de la transformación digital. Estamos ante una oportunidad, sin precedentes, de concienciar de la necesidad de impulsar la sostenibilidad y el talento digital sin olvidar a los trabajadores menos familiarizados con la digitalización. 
De toda esta problemática nos hablan con un lenguaje sencillo y un contenido riguroso Josep Lluís Micó y Patricia Coll. Micó es Profesor Catedrático de Periodismo en la Universidad Ramón Llul (URL), así como vicedecano de la Facultad de Comunicación y Relaciones Internacionales. Ha sido director del Grado en Periodismo y del Máster en Periodismo Avanzado. Igualmente, ha sido Investigador Principal de distintos proyectos de investigación, nacionales e internacionales, y ha colaborado con gigantes tecnológicos como Facebook o Google. Por su parte, la Profesora Coll tiene una sólida trayectoria en el ámbito de la comunicación, habiendo también sido directora del Grado de Periodismo y Comunicación Corporativa de la URL. Una de sus líneas de investigación es la comunicación y, en concreto, la transformación digital. Ambos autores están especializados en la tecnología digital.

A lo largo de la presente monografía, se pone de manifiesto como, en los últimos meses que hemos vivido, se ha producido lo que los autores denominan "hiperaceleración" que, por cierto, da título a la obra objeto de esta reseña. El libro es el comienzo de una nueva época de colaboración entre los seres humanos y las máquinas. Es, a partir de ahora, cuando asistimos a una revolución sin precedentes y los siguientes fenómenos tienen un valor absolutamente prioritario: la inteligencia artificial, el aprendizaje digital, la realidad virtual, el Internet de las Cosas (Internet of Things en inglés), la robótica, la computación en la nube, el 5G, los pagos digitales, la cadena de bloques -blockchain-, la telemedicina y las videoconferencias -a través de Zoom, Microsoft Teams y Google Meet, entre otras plataformas-, entre otros. A este último respecto, cabe indicar que la telemedicina resulta básica para sortear el colapso en los hospitales y centros de salud, pero también para el diagnóstico y tratamientos frente al coronavirus que en base a los mismos consiguen convertirse en procesos rápidos y sencillos. Como los autores señalan, la irrupción de la pandemia incidió, de manera sensible, en el contenido de la presente obra, pues fueron testigos y también protagonistas de la hiperaceleración, es decir, la intensificación de la revolución digital debido a las cuarentenas y confinamientos implementados a raíz de la pandemia. El COVID-19 es un reto para toda la humanidad y, naturalmente, para la ciencia. Asimismo, como decíamos al comienzo de la presente reseña, las nuevas tecnologías y la digitalización han acelerado su implantación en las empresas y en las tareas cotidianas de las sociedades. El coronavirus ha dinamitado las estructuras de economías avanzadas, modificando patrones de comportamiento decimonónico, generando un cambio disruptivo a nivel global.

Con acierto, se advierte que cuando el COVID-19 irrumpió, las sociedades se refugiaron tanto en la tecnología como en la ciencia para poder atenuar los efectos del desastre en ciernes. Inicialmente, gracias a los avances de la ciencia, se pudo tratar, a nivel sanitario, a los afectados por este complejo virus, $y$, posteriormente, se pudo asegurar la continuidad de las actuaciones profesionales y sociales en virtud de la conexión tecnológica. Asimismo, se hizo uso de software de rastreo para conocer los contactos que las personas tenían con otras. A todo ello coadyuvaron los programas específicos puestos en marcha por los gobiernos, pero también por Google y Apple. Estas últimas lanzaron la plataforma de notificación de exposición, que tiene como finalidad rastrear el coronavirus. En todo caso, para su instalación y procesamiento de los datos es necesario que los usuarios, para respetar las políticas de privacidad, den su consentimiento específico. 
Además de la relevancia de la tecnología, como los autores apuntan, debe prestarse especial atención a la innovación. Al respecto, determinan que la misma no es pragmática ni realista y que procede de la utopía, de la creatividad o, en definitiva, de la imaginación. No hay nada que esté escrito con carácter previo. Las empresas han de tener un alto nivel de tolerancia al fracaso, no tener miedo a experimentar, por complejo que resulte, naufragar y volver a actuar.

En los diversos capítulos de la obra, se pone de relieve como durante los últimos meses, la denominada cuarta revolución industrial se ha hiperacelerado. Asimismo, se describen las próximas innovaciones que están en camino que revelan una mayor vinculación con las máquinas. Existe una relevancia creciente de la inteligencia artificial. En suma, podemos establecer un símil con una popular serie actual, y afirmar que la presente monografía se erige en una suerte del Black Mirror de la realidad. Asistimos como protagonistas de un cambio inimaginable de paradigma. El mundo avanza hacia cambios exponenciales que progresan tan rápido como la pandemia que el mundo está afrontando. Es obvio que la ciencia avanza y, con ella, los cambios tecnológicos.

Ahora bien, desde los inicios de la presente pandemia, la información no ha evolucionado como sería deseable. Si hubiera sido la suficiente y en el momento adecuado, hubiéramos gestionado la pandemia a tiempo y no estaríamos en esta situación. Como los autores establecen, la ciencia evoluciona si puede hacer frente a los retos de su época. En definitiva, estamos ante una obra de ineludible referencia para tomar conciencia de todos los cambios que, en un plano interdisciplinar, estamos experimentando.

Patricia Vargas Portillo

Revisado por Alina Timóteo

\section{Ferreira, Fátima Moura; Fernandes, Eduardo (eds.) (2019), Representações de poder do Estado em Portugal e no Império (1950-1975). Porto: Circo de Ideias, 224 pp.}

Pode o edificado contribuir para potestade de um regime? A resposta a tal questão encontra-se nos ensaios que compõem a obra Representações de poder do Estado em Portugal e no Império (1950-1975), editada por Fátima Moura Ferreira e Eduardo Fernandes, resultado de um projeto de investigação efetuado pelo Lab2PT da Universidade do Minho, entre 2015 e 2017. Através de uma sólida base documental, e um foco analítico centrado no Norte e Centro de Portugal e em África (Moçambique e Angola), é trabalhada a articulação da arquitetura com o poder político estado-novista. De acordo com os editores, surge a intenção de "dinamizar estudos cruzados entre a arquitetura e a história” (p. 7), tema que tem suscitado interesse académico e de que são prova trabalhos destes ${ }^{1}$ e de outros autores ${ }^{2}$ bem como projetos recentes. ${ }^{3}$ Entre os contributos inéditos salientamos, desde logo, as datas escolhidas, uma vez que se tem dado maior atenção historiográfica à arquitetura oficial elaborada no período inicial do regime.

\footnotetext{
${ }^{1}$ Ferreira, Fátima Moura; Mendes, Francisco Azevedo; Pereira, Natália (coords.) (2016), A conquista social do território: arquitectura e corporativismo no Estado Novo português. Coimbra: Tenacitas.
} 
Sobre o conteúdo, o primeiro artigo "O Estado Novo através do país: obras públicas e imagética discursiva, entre a perenidade e a hibridez" (pp. 24-46) -, da lavra de Fátima Moura Ferreira, observa como a fotografia foi "ilustração paradigmática dos usos discursivos da imagem, entendida em termos de duplo enunciado entre o (in)visível e o (in) dizível” (p. 26). É feito uso de um conjunto de publicações periódicas e álbuns comemorativos nos quais a cartografia visual colocava as obras públicas como mecanismo propagandístico e amplificador de uma ideia de homogeneização modernizadora do país, ambicionando a divulgação de uma linguagem política centralizadora.

As dinâmicas ligadas ao processo de edificação operacionalizam-se com alguns casos de estudo. Os dois textos de Eduardo Fernandes e Rui Pereira - "A metáfora do Grifo na obra de Januário Godinho: entre modernismo, contextualismo e representação do poder" (pp. 47-80) e "Arquitetura em contracorrente: Raúl Rodrigues Lima e a construção de um modelo para os Palácios da Justiça no Estado Novo" (pp. 81-96) - demonstram como os arquitetos foram protagonistas de um movimento reformista no seio da ditadura. Não deixa de ser relevante ter sido em edifícios onde se exerciam formas muito concretas de poder (tribunais e câmaras municipais) que se procurou abrir espaço de diálogo, ainda que matizado, a outras formas de pensar e fazer arquitetura, abordagem frisada pelos autores. No mesmo sentido aponta o estudo de Vanda Maldonado - "Para uma ideia de liberdade e de democracia: o conjunto de habitação social em Benavente de Vítor Figueiredo" (pp. 149-163) -, apresentando a habitação social como um dos poucos refúgios de liberdade criativa, com implicações nos próprios modos de refletir a organização interna dos fogos. As três pesquisas sobre estes arquitetos individualizam uma atitude coletiva subentendida na mutação da gramática estética em estreita correlação com o contexto político coevo, atestando uma certa pluralidade de olhares.

Transpondo tais fundamentos para as então províncias ultramarinas surgem dois trabalhos. O primeiro é o de Elisário Miranda - "Monumentalidade, internacionalismo e pluralidade: o Banco Nacional Ultramarino em Moçambique" (pp. 97-125) onde é feito o levantamento dos empreendimentos efetuados por este banco no território moçambicano. O texto demonstra a preponderância de alguns arquitetos, muito influenciados pelo Movimento Moderno Internacional e pelo conceito de Gesamtkunstwerk (obra de arte total), provando o carácter plural em que a expressão material do pensamento arquitetónico se concebeu. Ainda sobre o espaço africano, mas com outro tema, Márcia C. F. Oliveira apresenta "Documentando politicamente a missão civilizadora imperial: o arquivo fotográfico da Companhia Diamang” (pp. 126-148). Através do tratamento arquivístico feito pela autora, é possível assinalar que esta companhia diamantífera documentou exaustivamente a sua atividade, nomeadamente

\footnotetext{
${ }^{2}$ Agarez, Ricardo Costa (coord.) (2018), Habitação: cem anos de políticas públicas em Portugal, 1918-2018. Lisboa: INCM/IHRU; Carvalho, Rita Almeida (2018), "Ideology and Architecture in the Portuguese 'Estado Novo': Cultural Innovation within a Para-Fascist State (1932-1945)”, Fascism, 7(2), 141-174.

${ }^{3}$ Entre outros, refira-se o projeto "Mapa da habitação: reflexão crítica sobre a arquitectura habitacional apoiada pelo Estado em Portugal (1910-1974)”, coordenado por Rui Jorge Garcia Ramos e sediado na Faculdade de Arquitectura da Universidade do Porto.
} 
no campo das infraestruturas. Como fundamentação para tal ocorrência, surge a noção da fotografia como veículo de autorrepresentação da Diamang e, tal como a atuação do Banco Nacional Ultramarino, como sustentáculo no esforço de modernização colonial empreendido, retórica muito útil em tempos de contestação interna e externa à presença portuguesa em África.

Da autoria de Natália Pereira, o capítulo "Corporativização do espaço rural: a esfera de ação dos grémios da lavoura no edificado corporativo" (pp. 164-178) analisa este tipo de organismos como plataforma comunicacional entre o poder central e os poderes locais, usando a sede do grémio pluriconcelhio de Abrantes, inaugurada em 1961, como exemplo da interlocução entre a ideia de poder e a sua realização prática. Refira-se que teria sido interessante a inclusão de um artigo que fizesse a análise do edificado legado por outros organismos corporativos - como por exemplo, os organismos de coordenação económica que pontilharam o país com diversos edifícios, desde os armazéns da Junta Nacional das Frutas aos silos da Federação Nacional dos Produtores de Trigo. Impactos na paisagem, perceção das comunidades locais e influência na estruturação do espaço envolvente poderão ser algumas pistas de investigação futura sobre esta questão, sem olvidar a estética que lhes está associada.

As conexões internacionais são alvo da atenção do artigo "Portugal's Urban Design under the Estado Novo: Foreign Influences Before and After the Second World War" (pp. 179-186), de Christian von Oppen. $\mathrm{O}$ autor refere que o design urbano foi uma das manifestações do poder político, com um notório ascendente do regime nazi sobre Portugal, algo que após 1945 se mostrou como um atavismo, permanecendo a resposta oficial arreigada a uma estética conservadora, contrariamente às propostas defendidas no I Congresso Nacional de Arquitectura (1948), no qual os arquitetos apresentariam um ideário mais permeável a influências modernas, existindo, assim, uma clara necessidade de adaptação.

Ainda no campo internacional, encontramos o último capítulo da obra, assinado por Antonio S. Río Vásquez - "Arquitectura y Estado en España, 1950-1975: de la autarquia à la transición" (pp. 187-206) - no qual se analisa arquitetura e história no contexto do franquismo, nomeadamente a forma como num período de crescimento económico se verificou, na arquitetura espanhola, "a recuperação da modernidade de um modo crítico e reflexivo" (p. 187; tradução do autor). A inclusão deste texto no livro parte da intenção dos editores em perceber o "binómio poder e arquitetura no país vizinho” (p. 9).

Além do que já foi escrutinado, algumas considerações adicionais podem ser feitas. O uso da iconografia (plantas, desenhos e fotografias) torna-se um importante auxiliador ao longo das páginas, constituindo um suporte para as reflexões tecidas pelos autores, destacando-se o conjunto de imagens patentes no final da Introdução (pp. 11-24), servindo como guia inicial dos temas versados e tornando-os mais tangíveis para o leitor. Sobre o espaço ultramarino, esta coletânea ganharia em profundidade se existisse estudos sobre Macau, Timor-Leste e a Índia, compreendendo a inserção destes territórios na reprodução da imagética e consolidação da presença política portuguesa. Terá havido investimento significativo de obras públicas nestas províncias? Haveria sensibilidade artística face aos elementos da cultura local? Estas são algumas questões em aberto para futuras abordagens.

Em conclusão, seguindo José Mattoso, "todo o poder tem a sua sede. Toda a 
sede ostenta os sinais de autoridade que nela reside". ${ }^{4}$ Asseverando tal ideia, esta monografia coletiva expõe como o desajuste entre um poder conservador e agentes organizacionais adeptos de mudanças resultou na discrepância entre modernidade e tradição. A representação do Estado apresentava um regime que caminhava para o seu ocaso e cujos progressos estilísticos se fizeram à custa de contributos individuais de arquitetos e instituições privadas, evidenciando "tonalidades plurais" (p. 10).

Leonardo Aboim Pires Revisto por Alina Timóteo

\section{Daniel Francisco}

Centro de Estudos Sociais, Universidade de Coimbra

Colégio de S. Jerónimo, Largo D. Dinis, Apartado 3087, 3000-995 Coimbra, Portugal

Contacto: danifran@fe.uc.pt

ORCID: https://orcid.org/0000-0003-3349-9592

\section{Maria Irene Ramalho}

Centro de Estudos Sociais, Universidade de Coimbra | Faculdade de Letras, Universidade de Coimbra Colégio de S. Jerónimo, Largo D. Dinis, Apartado 3087, 3000-995 Coimbra, Portugal

Contacto:mir@ces.uc.pt

ORCID: https://orcid.org/0000-0002-4428-547X

\section{Roberta Holanda Maschietto}

Investigadora em Pós-doutoramento, Centro de Estudos Sociais, Universidade de Coimbra

Colégio de S. Jerónimo, Largo D. Dinis, Apartado 3087, 3000-995 Coimbra, Portugal

Contacto: rhmaschietto@gmail.com

ORCID: https://orcid.org/0000-0002-6079-280X

\section{Patricia Vargas Portillo}

ESIC - Business \& Marketing School

Camino de Valdenigriales, s/n, 28223 Pozuelo de Alarcón, Madrid, España

Contacto: jennypatricia.vargas@esic.edu

ORCID: https://orcid.org/0000-0002-0226-3053

\section{Leonardo Aboim Pires}

Centro de Estudos Interdisciplinares do Século XX, Universidade de Coimbra

Rua Filipe Simões, n. ${ }^{\circ} 33$, 3000-186 Coimbra, Portugal

Contacto: leonardo.a.pires@uc.pt

ORCID: https://orcid.org/0000-0001-6033-350X

${ }^{4}$ Mattoso, José (1988), A escrita da história: teoria e métodos. Lisboa: Editorial Estampa. 
